\title{
Factors Affecting Logistics Providers' Satisfaction with Logistic Environment in Ho Chi Minh City
}

\author{
BÙI THANH TRÁNG \\ Doctor of philosophy, University of Economics HCMC \\ Email: trangbui@ueh.edu.vn \\ HỒ XUÂN TIÊN \\ HCMC College of Economics \\ Email: ho.xuantien@yahoo.com
}

\begin{abstract}
The paper investigates factors affecting logistics providers' satisfaction with HCMC logistic environment and then extend some remedies to enhance it. By using both quantitative and qualitative methods, the authors investigate 200 logistics providers operating in HCMC. The results show that the satisfaction with the logistic environment is affected by six factors: (1) the quality of trade-and transport-related infrastructure, (2) the ease of arranging competitively priced shipments, (3) the efficiency of the customs clearance process, (4) the ability to track and trace consignments, (5) the competence and quality of logistic services, and (6) the frequency with which shipments reach the consignee within the scheduled or expected delivery time.
\end{abstract}

Keywords: satisfaction, logistic environment, HCMC-based logistics providers 


\section{RATIONALE}

Vietnam, a country in the Southeast Asia, is endowed with a strategic location for international shipment which is facilitated by a long coastline and deep-sea ports. It possesses a great potential for development of logistic services which play a crucial role in the national economy and contribute a lot to the GDP. Logistics not only stimulates the development of thousands of domestic enterprises but also promotes the process of economic integration and commercial collaboration. It plays a crucial role in tackling input and output problems effectively; optimizing the circulation of materials, commodities and services; and thereby reducing costs and enhancing the enterprise's competitiveness.

Logistics is the spine of global commerce. An efficient logistic environment will increase economic growth. An appropriate policy and strategy is necessary to improve the logistic environment, which in turn will pave the way for the strong development of Vietnam's logistic service and its contribution to national socioeconomic development. Therefore, investigating factors affecting the satisfaction of HCMCbased logistics providers with logistic environment will help improve the logistic environment and Vietnam's logistics quality.

\section{THEORETICAL FRAMEWORK AND RESEARCH MODEL}

\section{a. Logistics and Logistics Performance Index (LPI):}

According to the American Logistics Association (1988), logistics is the process of planning, organizing and managing the transport and storage of consignments or services between the point of origin and the point of destination in order to meet some requirements of customers. In Vietnam, it first appeared in the 1970s. Logistic services are a kind of commercial activity, in which a provider organizes one or many tasks simultaneously including acceptance of consignment, shipment, warehousing, customs clearance, consultancy, packaging, coding, delivery and other services in accordance with agreements with customers to enjoy a remuneration (Commercial Law, 2005).

In order to evaluate the logistics performance of a country, the Logistics Performance Index (LPI) introduced by the World Bank is often employed (World Bank, 2007, 2010, 2012). LPI was first publicized in November 2007 and second in January 2010, third in May 2012 in a series of Connecting to Compete: Trade Logistics in the Global Economy. LPI is studied and measured by economists of the World Bank 
in collaboration with various international organizations, world big logistics providers and other academic partners.

As published in editions 2007 and 2010 by World Bank, LPI is composed of six factors:

- The efficiency of the customs clearance - hereunder called Customs.

- The quality of trade- and transport-related infrastructure - hereunder called Infrastructure.

- The ease of arranging competitively priced shipments - hereunder called International shipments.

- The competence and quality of logistic services - hereunder called Logistics quality and competence.

- The ability to track and trace consignments - hereunder called Tracking and tracing.

- The frequency with which shipments reach the consignee within the scheduled or expected delivery time - hereunder called Timeliness.

\section{b. An Overview of the Logistic Environment and Logistics Providers in Vietnam:}

Since Vietnam's accession to the WTO, its logistics market has made positive changes and the number of logistics providers has continuously risen. The annual revenue approximates US\$12 billion. According to World Bank, Vietnam, in 2011, was ranked $53^{\text {rd }}$ out of 155 countries in terms of LPI. With regard to the Liner Shipping Connectivity Index (LSCI) by the United Nations Conference on Trade and Development (UNCTAD), Vietnam was ranked $20^{\text {th }}$ out of 162 countries in 2012, a stable rise in past years. These figures show that Vietnam's logistics performance is moderate, which is an optimistic sign for Vietnam's logistics in upcoming years, especially when Vietnam builds deep-sea ports.

However, in the process of economic integration and at the regional level, Vietnam's logistics has exposed plenty of weakness in infrastructure, seaports, warehouses, logistics providers' competence, and especially high-quality human resources. Albeit plenty of investments have been poured in infrastructure, they are scattered and thus cannot establish a logistic hub with a convenient traffic network serving the development of logistics. Consequently, the asynchronous development of 
roads, railways, waterways, and airways, etc. has pushed Vietnam's logistics costs higher than those of neighboring countries and represented 25\% of GDP; and thereby spoiling the competitiveness of domestic logistic services. Therefore, it is necessary to develop seaports, wharves, freight yards, warehouses, inland clearance depots (ICD); invest in loaders and heavy equipment machines to load and transport commodities within the seaport, from ICDs to seaports and vice versa; and utilize IT breakthroughs effectively.

Development of logistics must be parallel with the development of shipping and containerization so as to meet customers' requirements quickly, safely, and efficiently. Seaports should be expanded and modernized in order to be able to accommodate container ships and keep up with the development of shipping industry in the world. The project of maritime transport development to 2020 approved by Vietnam's government also indicates that logistic services must be emphasized in parallel with the promotion of high-quality multiple modes of transportation services and then 3PL and 4PL services which can be provided across the border to meet integration requirements.

At present, there are 1,143 logistics providers, according to the statistics of Vietnam's Yellow and White Pages. Of them, limited liabilities companies account for $19 \%$, joint stock ones $19 \%$, and private ones $2 \%$. In HCMC alone, there are approximately 700 logistics providers. Albeit multinationals of this field are few, their market share is large, and the annual revenue is very high. In the meantime, Vietnamese firms, despite being more numerous than foreign ones, earn low revenue. According to Vietnam's Logistics Association, logistics providers are often granted a business term of five years at least. Majority of them are small-sized; and those with a capital smaller than VND1 billion represent 78\%, from VND1 billion to smaller than VND5 billion making up 15\%, from VND5 billion to VND10 billion being 4\% and more than VND10 billion constituting around 3\%. Due to the fact that the capital size is small, firms cannot acquire equipment and employ high-qualified human resources; and thus the service quality is inconsistent, professionalism is low, competitiveness is weak, and IT competence cannot keep up with other developed countries in Southeast Asia. Most of Vietnamese logistics providers have not established a representative office in foreign countries and lacked mutual support. Unfair competition by cutting service price to win the role as an agent for foreign companies is quite popular among Vietnamese logistics providers. 
In general, Vietnam's logistics providers, in the current context, have merely been acting as representatives of transporters. What they often take charge of includes notifying exporters and importers of the current status of their consignments, delivering consignments on the behalf of transporters to their customers, collecting shipment fees on the behalf of shippers, and the like; and thus cannot contribute much to the business performance of the logistics firm (Thanh Long, 2012). Therefore, in order to enhance the competitiveness of domestic logistics providers, it is necessary to boost the service quality and policy markers should create favorable conditions for logistics providers to improve themselves and perform effectively in this potential field.

Vietnam's logistics is infant and is supposed to develop rapidly if the business climate is improved. Hence, studying factors affecting the satisfaction with logistic environment by HCMC-based logistics providers is a more practical approach.

\section{c. Research Model Suggested and Hypotheses:}

Based on the LPI assessments of Arvis et al. (2007), the author consulted experts who have many years of experiences in logistics in HCMC to investigate the influential level of six components of LPI.

The efficiency of the customs clearance refers to quick customs procedures, simple formalities for exports and imports, and the absence of corruption during the custom clearance. The quality of trade- and transport-related infrastructure is related to the convenient location of seaports, availability of loaders, the roadway system within the seaport, application of IT to make use of seaport services. The ease of arranging competitively priced shipments refers to the competence of shippers to meet customers' needs and availability of multiple choices of services. The competence and quality of logistic services refers to the ability, professionalism and experience of managers and staff of logistics providers to secure the safety of consignments, provide full-package services, and meet various needs of customers. The ability to track and trace consignments is construed that customers are always kept informed of their consignment status through dedicated software. The final component is the timeliness or the frequency with which shipments reach the consignee within the scheduled or expected delivery time. 
Given the aforementioned theoretical background, factors affecting the satisfaction of HCMC-based logistics providers with local logistic environments are presented in Figure 1.

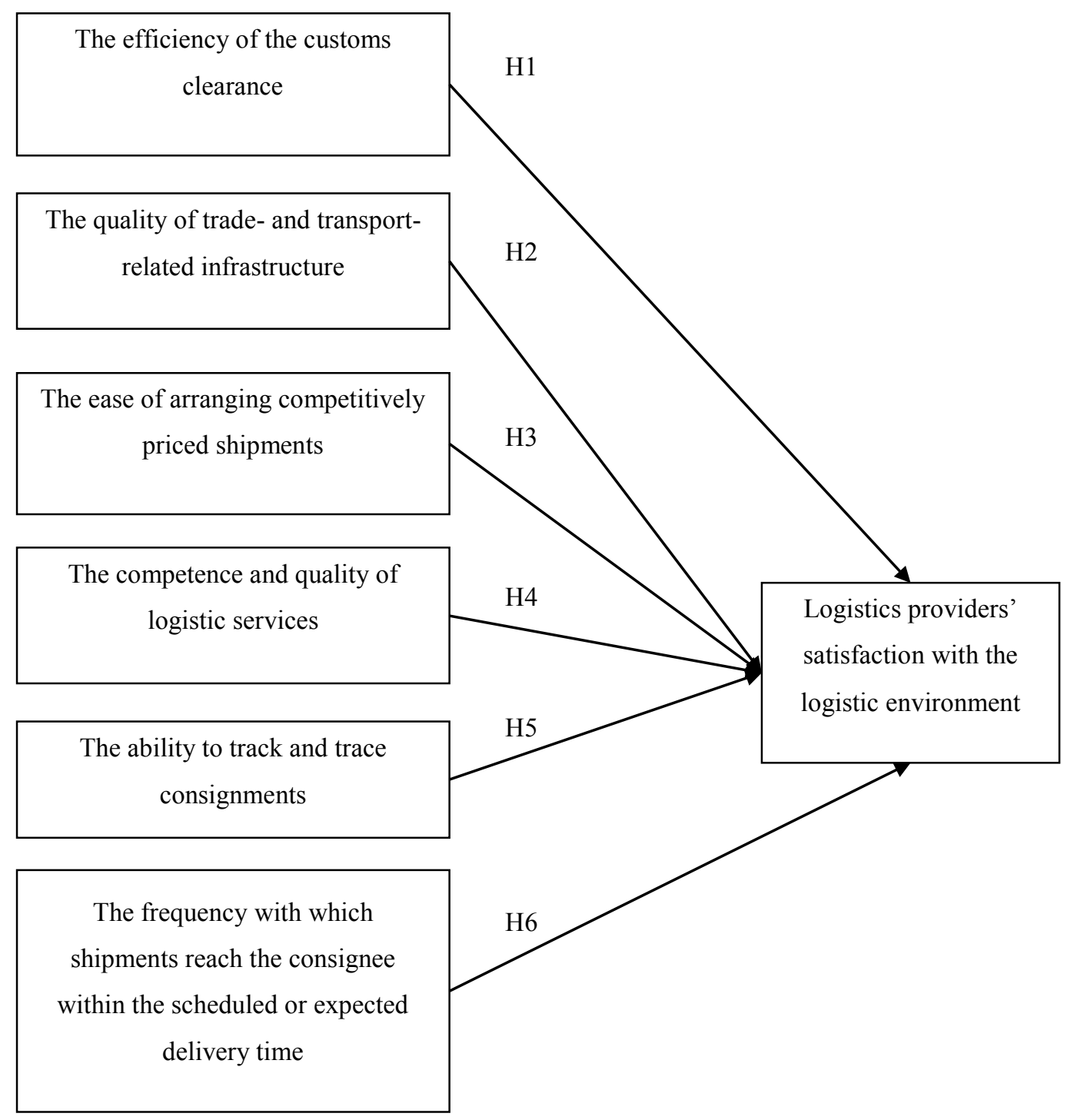

Figure 1: Research Model 
It is hypothesized that:

H1: The more efficient the customs clearance, the more the logistics providers satisfied with the logistic environment.

$\mathrm{H} 2$. The higher the quality of trade- and transport-related infrastructure, the more the logistics providers satisfied with the logistic environment.

H3: The easier the arrangement of competitively priced shipments, the more the logistics providers satisfied with the logistic environment.

H4: The higher the competence and quality of logistic services, the more the logistics providers satisfied with the logistic environment.

H5: The higher the ability to track and trace consignments, the more the logistics providers satisfied with the logistic environment.

H6: The higher the frequency with which shipments reach the consignee within the scheduled or expected delivery time, the more the logistics providers satisfied with the logistic environment.

\section{METHODOLOGY}

The research is conducted both qualitatively and quantitatively. In the qualitative research, the author conducts ten in-depth interviews with logistics experts to discover factors affecting the logistic environment satisfaction by HCMC-based logistics providers. It is found that there are 41 observed variables to be employed to determine six influential factors. Of them, there are eight observed variables for the Customs clearance, six for Logistics competence and quality, seven for International shipments, six for Infrastructure, six for Tracking and tracing, five for Timeliness, and three for Satisfaction.

In the quantitative research, the author conducts in-depth interviews with managers and office heads of $240 \mathrm{HCMC}$-based logistics providers. The response ratio is $83 \%$ and there are 200 appropriate questionnaires for further analyses. Of chosen firms, state-owned enterprises account for $25 \%$, foreign-invested enterprises represent $16 \%$ and non-public enterprises constitute 59\% (Figure 2). 


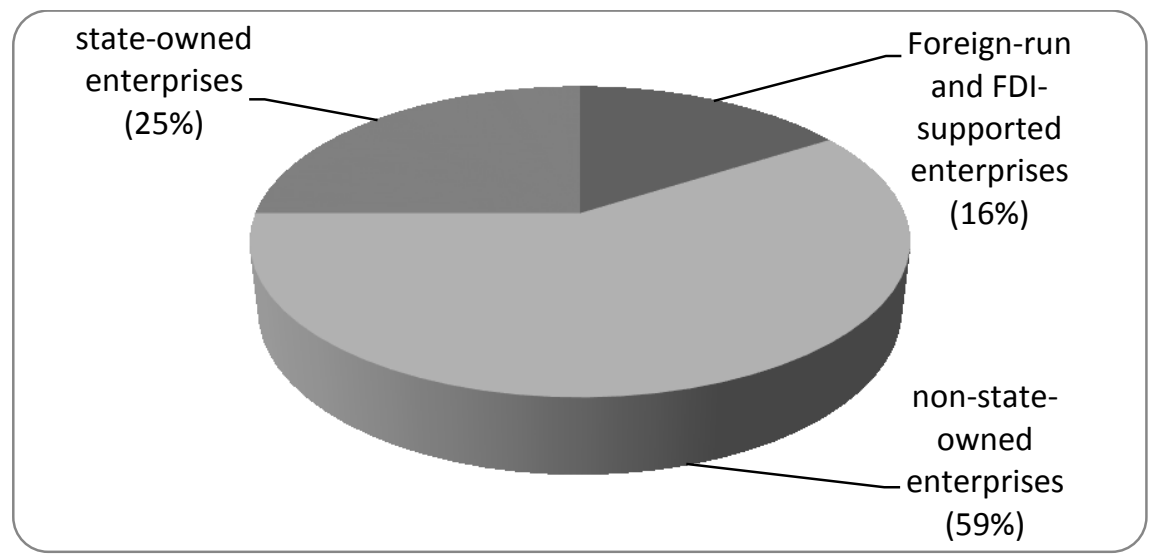

Source: Research results

Figure 2: Research Sample

\section{RESEARCH RESULTS}

\section{a. Testing Measurement Scales:}

The measurement scale of factors affecting the satisfaction with the local logistic environment is tested by Cronbach's Alpha and EFA. As the Cronbach's Alpha results (Table 1) indicate, the reliability of measurement scales are exceptionally high (Cronbach's alpha $>0.8$ ). The total-item correlation coefficients of variables are larger than 0.3; and thus it is acceptable and is used for the EFA.

\section{Table 1: Measurement Scale Testing Results}

\begin{tabular}{clc}
\hline No. & \multicolumn{1}{c}{ Components } & Cronbach's Alpha \\
\hline 1 & The efficiency of customs clearances (CS) & 0.930 \\
2 & The quality of trade- and transport-related infrastructure (IF) & 0.945 \\
3 & The ease of arranging competitively priced shipments (IS) & 0.912 \\
4 & The competence and quality of logistic services (LC) & 0.878 \\
5 & The ability to track and trace consignments (TT) & 0.892 \\
6 & $\begin{array}{l}\text { The frequency with which shipments reach the consignee } \\
7\end{array}$ & within the scheduled or expected delivery time (TL) \\
\hline
\end{tabular}

Source: Results of scale test based on surveyed data 
To perform EFA, the principal component analysis and the Varimax rotation are often employed. As Table 2 indicates, components, after omitting dummy variables, are acceptable with the factor loading of observed variables larger than 0.5 (Hair et al, 1998). The Bartlett's test produces a Sig. $=0.000$ and the KMO coefficient is 0.934 . Of all 41 variables, after EFA, there are 33 acceptable variables which are extracted into seven factors with Eigenvalues larger than 1 and the extracted variance larger than $50 \%$. Therefore, extracted measurement scales are acceptable. EFA results reveal that the research model is stable (i.e. six independent variables and one dependent remain unchanged) and is suitable to conduct multiple linear regression analyses.

\section{b. Multiple Linear Regression Analysis:}

The Pearson correlation coefficient is used to test the linear correlation between the independent variables and the dependent one. The matrix of correlation coefficients (Table 3) shows that the "satisfaction with the logistic environment" has a strong linear correlation with six independent variables at the $\alpha \leq 0.05$; and the correlation coefficients of variables range between 0.227 and 0.668 , and thus satisfying the condition $-1 \leq \mathrm{r} \leq+1$. In brief, all variables are accepted to perform multiple linear regression analyses, and measurement scales can measure various research concepts. As the matrix of correlation coefficients indicates, the "infrastructure" has the strongest impacts on the dependent variable.

Table 2: EFA Results

\begin{tabular}{|c|c|c|c|c|c|c|c|c|}
\hline \multirow{2}{*}{ Variable } & \multirow{2}{*}{ Descriptions } & \multicolumn{6}{|c|}{ Factors } & \multirow{2}{*}{ SAS } \\
\hline & & CS & IF & IS & TL & LC & TT & \\
\hline CS1 & $\begin{array}{l}\text { E-customs declarations } \\
\text { are quick. }\end{array}$ & 0.743 & & & & & & \\
\hline $\mathrm{CS} 2$ & $\begin{array}{l}\text { Customs offices often } \\
\text { hold customs talks. }\end{array}$ & 0.781 & & & & & & \\
\hline $\mathrm{CS} 3$ & $\begin{array}{l}\text { Changes in duty rates are } \\
\text { immediately notified to } \\
\text { enterprises. }\end{array}$ & 0.741 & & & & & & \\
\hline $\mathrm{CS} 4$ & $\begin{array}{l}\text { Term of customs } \\
\text { clearance for imports is } \\
\text { appropriate. }\end{array}$ & 0.761 & & & & & & \\
\hline
\end{tabular}




\begin{tabular}{|c|c|c|c|c|}
\hline CS5 & $\begin{array}{l}\text { Term of customs } \\
\text { clearance for exports is } \\
\text { short. }\end{array}$ & 0.776 & & \\
\hline CS6 & $\begin{array}{l}\text { No corruption is found } \\
\text { during the customs } \\
\text { clearance. }\end{array}$ & 0.632 & & \\
\hline CS7 & $\begin{array}{l}\text { The ratio of customs } \\
\text { check is appropriate. }\end{array}$ & 0.706 & & \\
\hline CS8 & $\begin{array}{l}\text { Customs dossiers } \\
\text { submitted to customs } \\
\text { bureaus are few. }\end{array}$ & 0.707 & & \\
\hline IF1 & $\begin{array}{l}\text { Equipment of the } \\
\text { seaports is always } \\
\text { available. }\end{array}$ & & 0.789 & \\
\hline IF2 & $\begin{array}{l}\text { The location of seaports } \\
\text { is convenient to } \\
\text { transportation. }\end{array}$ & & 0.833 & \\
\hline IF3 & $\begin{array}{l}\text { It is convenient to } \\
\text { transport commodities } \\
\text { by ferries. }\end{array}$ & & 0.801 & \\
\hline IF4 & $\begin{array}{l}\text { The roadways leading to } \\
\text { seaports are through and } \\
\text { in good conditions. }\end{array}$ & & 0.804 & \\
\hline IF5 & $\begin{array}{l}\text { IT applications are } \\
\text { effectively employed to } \\
\text { operate the seaport. }\end{array}$ & & 0.788 & \\
\hline IS1 & $\begin{array}{l}\text { The capacity of shippers } \\
\text { meets the customers' } \\
\text { need. }\end{array}$ & & & 0.677 \\
\hline IS3 & $\begin{array}{l}\text { Maritime logistics } \\
\text { providers are numerous } \\
\text { and diverse. }\end{array}$ & & & 0.689 \\
\hline IS4 & $\begin{array}{l}\text { There are direct transport } \\
\text { routines to the European }\end{array}$ & & & 0.759 \\
\hline
\end{tabular}


market.

IS5 It is easy to arrange

competitively priced $\quad 0.745$

shipments.

IS6 There are direct transport

routines to the North

American market.

\begin{tabular}{|c|c|c|c|c|}
\hline TL1 & $\begin{array}{l}\text { Shipments reach the port } \\
\text { of destination within the } \\
\text { scheduled or expected } \\
\text { delivery time. }\end{array}$ & 0.773 & & \\
\hline TL2 & $\begin{array}{l}\text { Commodities are } \\
\text { transported exactly as } \\
\text { notified }\end{array}$ & 0.719 & & \\
\hline TL3 & $\begin{array}{l}\text { There is no } \\
\text { postponement of } \\
\text { departure date. }\end{array}$ & 0.750 & & \\
\hline TL4 & $\begin{array}{l}\text { There are few incidents } \\
\text { concerning maritime } \\
\text { transport. }\end{array}$ & 0.619 & & \\
\hline LC1 & $\begin{array}{l}\text { Logistic costs are } \\
\text { competitive. }\end{array}$ & & 0.615 & \\
\hline LC2 & $\begin{array}{l}\text { Competence and } \\
\text { professionalism of } \\
\text { logistics staff meets } \\
\text { customers' needs. }\end{array}$ & & 0.683 & \\
\hline LC3 & $\begin{array}{l}\text { Loss of consignments } \\
\text { has never occurred. }\end{array}$ & & 0.761 & \\
\hline LC4 & $\begin{array}{l}\text { Bylaws of logistics } \\
\text { operation are manifest. }\end{array}$ & & 0.722 & \\
\hline TT3 & $\begin{array}{l}\text { Software used to track } \\
\text { and trace consignments } \\
\text { provide adequate } \\
\text { information. }\end{array}$ & & & 0.660 \\
\hline
\end{tabular}




\begin{tabular}{|c|c|c|c|c|c|c|c|c|}
\hline TT4 & $\begin{array}{l}\text { Information of accidents } \\
\text { is notified to the } \\
\text { provider in time. }\end{array}$ & & & & & & 0.661 & \\
\hline TT5 & $\begin{array}{l}\text { It is easy to require } \\
\text { logistic information from } \\
\text { service providers. }\end{array}$ & & & & & & 0.733 & \\
\hline TT6 & $\begin{array}{l}\text { Logistics providers } \\
\text { regularly notify } \\
\text { customers of the } \\
\text { consignments' status. }\end{array}$ & & & & & & 0.740 & \\
\hline SAS1 & $\begin{array}{l}\text { I am satisfied with the } \\
\text { logistic environment. }\end{array}$ & & & & & & & 0.940 \\
\hline SAS2 & $\begin{array}{l}\text { I am pleased with the } \\
\text { provided logistic } \\
\text { services. }\end{array}$ & & & & & & & 0.929 \\
\hline SAS3 & $\begin{array}{l}\text { I believe in the strong } \\
\text { development of } \\
\text { Vietnam's logistics. }\end{array}$ & & & & & & & 0.866 \\
\hline \multicolumn{2}{|c|}{ Eigenvalues } & 13.647 & 2.104 & 1.840 & 1.422 & 1.302 & 1.135 & 2.498 \\
\hline \multicolumn{2}{|c|}{ Extracted variance $(\%)$} & 18.224 & 14.018 & 11.741 & 9.396 & 9.096 & 9.023 & 83.276 \\
\hline
\end{tabular}

Source: EFA results based on surveyed data

Table 3: Matrix of Correlation Coefficients

\begin{tabular}{lccccccc}
\hline & CS & IF & IS & TL & LC & TT & SAS \\
\hline Customs (CS) & 1 & 0.000 & 0.000 & 0.000 & 0.000 & 0.000 & $0.411^{* *}$ \\
Infrastructure (IF) & 0.000 & 1 & 0.000 & 0.000 & 0.000 & 0.000 & $0.668^{* *}$ \\
International shipments (IS) & 0.000 & 0.000 & 1 & 0.000 & 0.000 & 0.000 & $0.654^{* *}$ \\
Timeliness (TL) & 0.000 & 0.000 & 0.000 & 1 & 0.000 & 0.000 & $0.285^{* *}$ \\
$\begin{array}{l}\text { Logistics quality and } \\
\text { competence (LC) }\end{array}$ & 0.000 & 0.000 & 0.000 & 0.000 & 1 & 0.000 & $0.227^{* *}$ \\
Tracking and tracing (TT) & 0.000 & 0.000 & 0.000 & 0.000 & 0.000 & 1 & $0.354^{* *}$
\end{tabular}


Satisfaction (SAS)

$0.411^{* *} \quad 0.668^{* *} \quad 0.654^{* *} \quad 0.285^{* *} \quad 0.227^{* *} 0.354^{* *}$

** denotes the statistically significant level at $10 \% ; \mathrm{N}=200$

Source: Correlation analysis results based on surveyed data

Table 4: Linear Regression Results

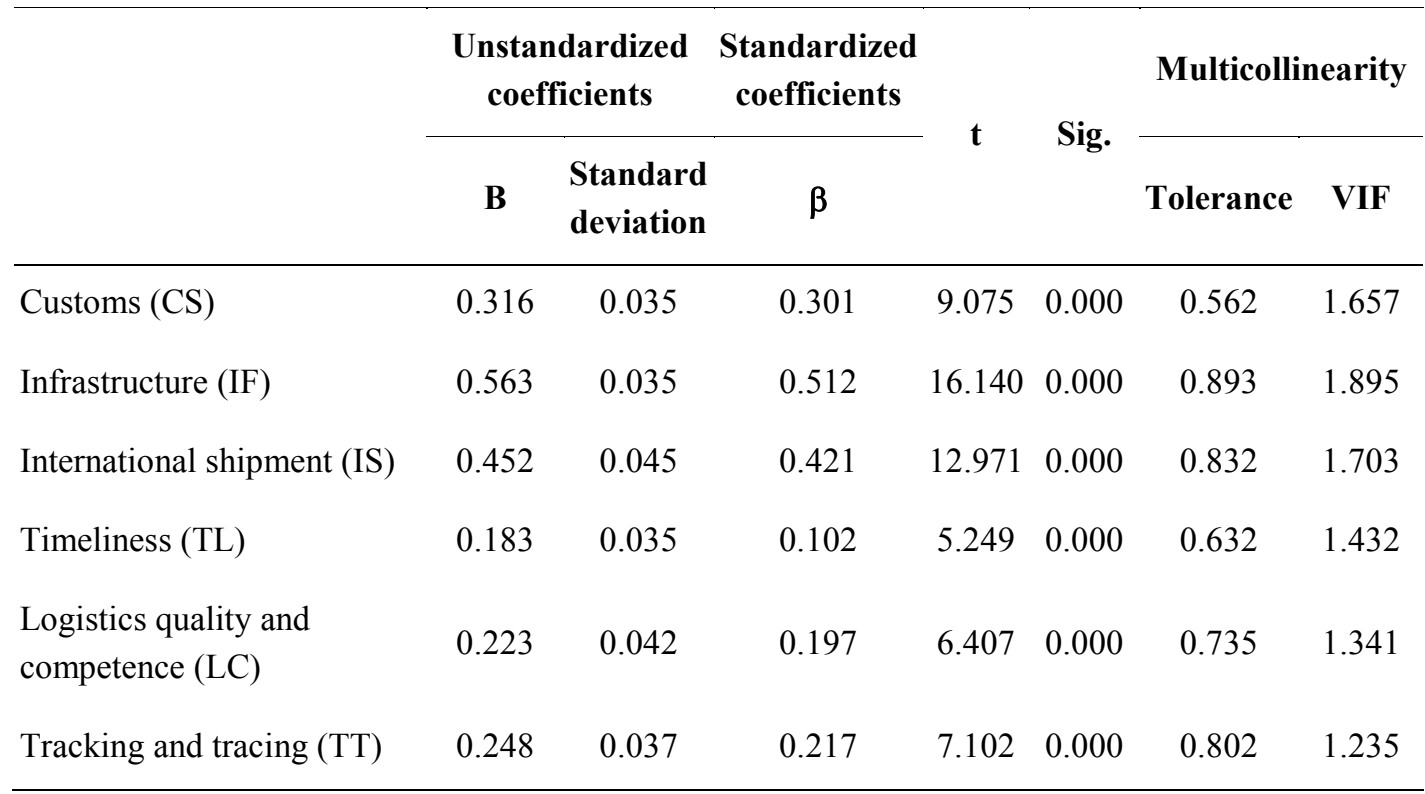

Source: Regression analysis results based on surveyed data

The Enter method is employed to analyze the multiple linear regression of factors affecting the logistic environment satisfaction. Table 4 shows that the relationship of six influential factors namely Customs (CS), Infrastructure (IF), International shipment (IS), Logistics competence and quality (LC), Tracking and tracing (TT), and Timeliness (TL) with the logistic environment satisfaction by logistics providers has the significance value smaller than 0.05 . The adjusted $R^{2}$ is 0.758 , and thus the goodness of fit of the multiple linear regression model reaches $75.8 \%$; or in other words, $75.8 \%$ of the logistic environment satisfaction is affected by six stated factors while the remaining $(24.2 \%)$ is influenced by other factors. The low tolerance and the VIF smaller than 2 prove that no multicollinearity is found and there is no close correlation among independent variables. Therefore, it can be concluded that the regression model fits the data set and variables are statistically significant at the 5\% 
level. Hypotheses 1 to 6 are acceptable. The linear regression model can be written as follows:

$$
\mathrm{Y}=0.316 * \mathrm{X}_{1}+0.563 * \mathrm{X}_{2}+0.452 * \mathrm{X}_{3}+0.183 * \mathrm{X}_{4}+0.223 * \mathrm{X}_{5}+0.248 * \mathrm{X}_{6}
$$

Where, $\mathrm{Y}$ denotes the logistic environment satisfaction by logistics providers; $\mathrm{X}_{1}$ is Customs, $X_{2}$ is Infrastructure, $X_{3}$ is International shipment; $X_{4}$ is Timeliness, $X_{5}$ is Logistics competence and quality, and $\mathrm{X}_{6}$ is Tracking and Tracing.

\section{CONCLUSION AND SUGGESTIONS}

As the paper indicates, there are six factors affecting satisfaction of HCMC-based logistics providers with logistic environment; and the influential level for each factor is different.

- Infrastructure (IF) has the strongest impacts on the satisfaction, with the regression coefficient of 0.563 .

- International shipment (IS) has the regression coefficient of 0.452 .

- The regression coefficient of Customs (CS) is 0.316 .

- The regression coefficient of Tracking and tracing (TT) is 0.248 .

- The regression coefficient of Logistics quality and competence (LC) is 0.223 .

- The regression coefficient of Timeliness (TL) is 0.183.

According to the aforementioned analyses, the quality of trade- and transportrelated infrastructure has the strongest impact on the satisfaction with the logistic environment, and the efficiency of the customs clearance is ranked third. The findings are congruent with LPI ranking of World Bank (2007, 2009, 2012), which states that the quality of trade- and transport-related infrastructure and the efficiency of the customs clearance are two greatest concern in low- or average-income countries.

Based on research findings, it is advised that:

Firstly, the roadway system should be upgraded to meet the increasing demand for transport in HCMC. The infrastructure of seaports in the Eastern South region should be developed in parallel to the development of roadways, railways, airways and waterways to assure the smooth transportation of consignments. Besides, it is an urgent need to move local seaports along the Saigon River to Cát Lái, Hiệp Phước and Cái Mép - Thị Vải to reduce the transport pressure in the inner city. Moreover, it is necessary to adopt preferential tax policies and enable enterprises to invest in the 
inner-city waterway system so as to make the best use of natural advantages of river system in HCMC.

Secondly, a state-of-the-art fleet of container ships should be developed to meet the need of maritime transport and fleets of small vessels for local transport (i.e. 500 2,000 TEU vessels for Asian routes, and 2000 - 6000 TEU vessels for European and American routes). However, the development of a fleet of container ships must be parallel with its competitiveness in order to be able to compete with foreign ones and avoid a massive acquisition of vessels without gaining large market share.

Thirdly, the Prime Minister's Decision 48/2011/QĐ-TTg dated Aug. 31, 2011 concerning the pilot execution of a national one-door customs regime must be stringently observed. Accordingly, by 2014, the term of customs clearance for imports and exports would be one day for air transport and 2.6 days for maritime transport. In addition, customs formalities should be reformed to facilitate the quick and effective customs clearance for imports and exports.

Finally, logistics providers should invest in IT and employ dedicated software to facilitate the business and transaction with both local and foreign customers. IT is an urgent requirement: it not only helps track the consignment status but also settle etransaction documents. Logistics providers should enhance the professional competence of their staff and open IT training courses to boost the competitiveness.

\section{LIMITATIONS AND SUGGESTIONS FOR FURTHER RESEARCH}

Albeit the paper has extended certain contributions in terms of theory and practice, there are some limitations. Due to the fact that samples are chosen conveniently, the generalization is restricted. Moreover, the measurement scales are only measured by the Cronbach's Alpha and EFA; and the theoretical model is tested by correlation coefficients and the multiple linear regression analyses. Thus, it is advised to test the theoretical model by other methods such as SEM which can both test hypotheses and determine the causality of research concepts

\section{References}

Đăng Quang (2010), "Hiện trạng cảng container TP.HCM và vùng phụ cận - Một cập nhật cho các doanh nghiệp xuất nhập khẩu và hãng tàu”, Vietnam Shipper, Vol.67, pp.38-42, Vol.68, pp.3437, Vol.69, pp.40-42.

Đoàn Thị Hồng Vân \& Kim Ngọc Đạt (2010), Logistics - Nhũng vấn đề co bản, Lao động- Xã hội Publisher, Hà Nội. 
Hair, J.F., R.E. Anderson, R.L. Tatham \& W.C. Black (1998), Multivariate Data Analysis, New Jersey: Prentice-Hall.

Narin Phol (2010), “3PL View on New Trends in Supply Chain Management”, proceedings of Vietnam Logso Exhibition 2010 held by Vietnam Supply Chain Insight Magazine on 29/7/2010.

Nguyễn Hùng (2012), "Logistics Việt Nam: 5 năm sau WTO (2007-2012)", Vietnam Shipper, Vol.53, 19.

Nguyễn Hùng (2011), "Logistics Việt Nam bước qua thời kỳ non trẻ”, Vietnam Logistics Review, Vol.49, pp.8-10.

Nunnally, J. \& I.H. Bernstein (1994), Psychometric Theory, 3rd Ed., New York: McGraw-Hill.

Parasuraman, A, V.A. Zeithaml \& L.L. Berry (1988), "SERVQUAL: A Multi-item Scale for Measuring Consumer Perceptions of Service Quality", Journal of Retailing, Vol 64(1), pp.1237.

Parasuraman, A., V.A. Zeithaml \& L.L. Berry (1985), “A Conceptual Model of Service Quality and Its Implications for Future Research”, Journal of Marketing, Vol.49(4), pp.41-50.

Thanh Long (2012), "Yếu logistics- Doanh nghiệp xuất khẩu gặp khó”, Vietnam Shipper, Vol.1, pp. 40- 41 .

Vietnam's National Assembly (2005), Commercial Law.

World Bank (2007, 2010, 2012), Connecting to Compete - Trade Logistics in the Global Economy. 